\title{
Differences in morphological parameters of judo athletes of different age groups and performance level
}

\author{
Miloš Štefanovský*, Stanislav Kraček, Il’ja Č́̌̌̌, and Karin Czibulová \\ Faculty of Physical Education and Sport, Comenius University in Bratislava, Bratislava, Slovakia
}

Copyright: (c) 2017 M. Štefanovský et al. This is an open access article licensed under the Creative Commons Attribution License (http://creativecommons.org/licenses/by/4.0/).

\begin{abstract}
Background: Some studies have pointed out the influence of morphological parameters on judo performance, however the relationship between morphological variables and performance status have not yet been confirmed. In addition, there is a lack of studies focused on morphological comparison of different age categories. Objective: The aim of this study was to assess differences in the morphological parameters of judo athletes of different age and performance level. Methods: The research sample was composed of 47 male judokas (age $19.15 \pm 2.93$ years; body weight $77.16 \pm 11.39 \mathrm{~kg}$; height $178.91 \pm 6.39 \mathrm{~cm}$; sport age $11.47 \pm 2.74$ years). It was divided by: (1) age, into cadets (15-17 years, $n=19)$, juniors (18-20 years, $n=15)$, and seniors (21+ years, $n=13)$ category and (2) performance status (elite, $n=10$; non-elite, $n=37$ ). In all participants, body fat, and the circumference measurement of wrist, forearm, flexed arm, and calf were observed. A personal interview was used to gain information about the athlete's performance status. Results: We found out that there are significant differences in arm circumference between cadets and seniors, cadets and juniors, juniors and seniors; and in the circumference of forearm between cadets and seniors; cadets and juniors, as well. According to the performance status, we have discovered significantly higher circumference of forearm and wrist in the elite group compared to the non-elite group. Conclusion: Forearm and wrist circumference is a reliable discriminative factor and should be taken into consideration, especially when selecting judo athletes into elite teams. However, we did not confirm that subcutaneous fat is a parameter able to distinguish between judo athletes of different performance status across various age categories.
\end{abstract}

Keywords: body fat, circumference measurement, elite, non-elite judokas

\section{Introduction}

Judo is an Olympic sport, which requires technique, tactics, and a high level of physical fitness (Little, 1991). Psychological aspects are important for success as well, especially emotional stability, concentration, level of stress tolerance, and anxiety (Štefanovský, 2009). Competitors attempt to maximize lean tissue mass, minimize body fat, and minimize total bodyweight (Franchini, Del Vecchio, Matsushigue, \& Artioli, 2011). Strength training using the athlete's own body weight to provide resistance is a common preparation for the sport. In terms of somatotype, most judo athletes are mesomorphs and endo-mesomorphs, depending on weight category (Štefanovský, 2015).

\footnotetext{
* Address for correspondence: Miloš Štefanovský, Department of Gymnastics, Faculty of Physical Education and Sports, Comenius University in Bratislava, Nábrežie armádneho generála Ludvíka Svobodu 42e98/9, 81469 Bratislava, Slovakia. E-mail: milos.stefanovsky@fsport.uniba.sk
}

The highest-performing male judo athletes usually have less than $10 \%$ body fat; the highest-performing females measure close to $16 \%$ body fat (Escobar-Molina et al., 2011). Judo competitors are also divided by age into cadets (15-17 years), juniors (18-20 years), seniors (+21 years), and masters ( +30 years). According to latest competition rules, the duration of the judo match was shortened from 5 to 4 minutes. A judo match consists of approximately 11 sections (Castarlenas, \& Planas, 1997; Marcon, Franchini, Jardim, \& Neto, 2010). In each section judokas try to initiate contact with the opponent using different kinds of grips, followed by attempts to break the balance and throw each other to the ground. After landing on the mat (tatami) both fighters strive to score by using techniques of immobilisation, arm locks and chokes. The effort-pause ratio during one section is between $2: 1$ and $3: 1$, with $20 \mathrm{~s}$ and $30 \mathrm{~s}$ effort periods and $10 \mathrm{~s}$ of pauses. Judo combat relies on all three metabolisms - anaerobic alactic, lactic system and aerobic system (Franchini, Artioli, \& Brito, 2013). 
As judo is a weight-class sport, few studies suggested that elite judo athletes presented lower body fat compared to non-elite athletes (Callister, Staron, Fleck, Tesch, \& Dudley, 1991; Kubo et al., 2006). According to studies of Franchini, Takito, Kiss, and Sterkowicz (2005) and Classens, Beunen, Wellens, and Geldof (1987), elite judokas compared to non-elite judokas had a higher circumference of flexed arm, forearm, wrist and medial calf and breadths of humerus and femur epicondyles. In a recent study, Drid et al. (2015) also confirmed significant differences in some morphological variables in elite groups of judo athletes (European and World medallist) compared to non-elite (only national medallist) groups. Moreover, elite judokas seem to have higher arm muscle mass than sub-elite athletes, but a similar body fat percentage.

On the other hand, Krstulović, Sekulić, and Sertić (2005) have measured morphological variables on 34 Croatian judo athletes of cadet age (15-16 years old) of different performance status. The sample of morphological variables included body weight, height, wrist breadth, forearm girth, calf girth and skinfold thickness. The authors concluded that observed morphological characteristics are not directly related to success in cadet judo competition. Franchini et al. (2005) did not find any significant differences in body fat and skinfold thickness between elite and non-elite judo athletes. Two years later, Franchini, Nunes, Moraes, and Del Vecchio (2007) studied the morphological parameters on the Brazilian national A-team and on the reserves (B and C team); they also did not confirm any differences in the following anthropometrical variables: femur, humerus and wrist diameter, arm, forearm, wrist, thorax, waist, gluteus and medial calf circumference.

When the age criterion was taken into consideration, few differences in morphological variables were presented in one study, where judo cadets presented smaller flexed arm circumference and humerus epicondyle bond breadth compared to juniors and seniors, and lower absolute muscle mass compared to seniors (Franchini et al., 2011).

The aim of our research was to compare some morphological variables of male judo athletes of different age and performance status. Our hypothesis was that morphological variables would be statistically different among the age groups (cadets, juniors, and seniors) and will discriminate elite from non-elite judo athletes.

\section{Methods}

\section{Participants}

The research sample was composed of 47 male judokas (age $19.15 \pm 2.93$ years; body weight $77.16 \pm 11.39 \mathrm{~kg}$; height $178.91 \pm 6.39 \mathrm{~cm}$; sport age $11.47 \pm 2.74$ years) representing eight different European countries (Croatia, Ukraine, Slovenia, Hungary, Poland, Austria, Czech and Slovak Republic), who took part in the training camp "V4" in Bratislava in 2015. At first, the research sample was divided according to their age into cadet (15-17 years; $n=19)$, junior $(18-20$ years; $n=15)$, senior $(21+; n=13)$ category. Then we have divided the athletes according their performance level into elite group $(n=10)$ and non-elite group $(n=37)$. In the cadet category, one athlete was from elite group and eighteen athletes from non-elite group. In the junior category, five judokas were classified as elite and ten as non-elite athletes. In the senior category, four judokas were elite and nine non-elite athletes. All participants took part voluntarily in the study. In case of underage participants, an informed consent agreement form was signed by their legal guardians. The study design was approved by the local Ethics Committee. None of the athletes in our study were from the heavy weight category $(+100 \mathrm{~kg})$ and none of the athletes were engaged in any weight loss procedure during the training camp and measurement procedures.

\section{Procedure}

Measurement procedures took place during the two morning judo sessions during the camp. Body weight and height were measured first, and then ultrasound technology (BodyMetrix, IntelaMetrix, Brentwood, CA, USA) was used to assess total body fat. BodyMetrix device offers different kind of protocols to assess the total body fat. In our study, we used the 9-site Parrillo protocol, where skinfold thickness was measured at nine locations of the body: chest, abdomen, thigh, biceps brachii, triceps brachii, subscapular, suprailiac, lower back and calf (Parrillo \& Greenwood-Robinson, 1993).

The fundamental principle of ultrasound imaging is the reflection of ultrasound waves from tissue in the path of the beam. The amount of sound reflected is dependent on the changes in acoustic impedance between two tissue interfaces. Acoustic impedance is the product of tissue density and acoustic velocity (Bushberg, Seibert, Leidholdt, \& Boone, 2002). Air has almost no impedance, while fat and muscle have impedances from $0.138 \mathrm{~g} \cdot \mathrm{cm}^{-1} \cdot \mathrm{s}^{-1}$ to $0.170 \mathrm{~g} \cdot \mathrm{cm}^{-1} \cdot \mathrm{s}^{-1}$, respectively, and bone has a relatively high impedance of $0.78 \mathrm{~g} \cdot \mathrm{cm}^{-1} \cdot \mathrm{s}^{-1}$ (Wagner, 2013).

The next procedure was the circumference measurements of the flexed arm, forearm, wrist, and calf. The circumferences were measured once at each point by the experienced evaluator, who presented less than $0.91 \%$ of variation between measurements.

The final part of the protocol was an interview with the athletes regarding their sports performance. We 
used this information to divide the judo athletes into elite and non-elite groups. The athletes who placed at least in the $5^{\text {th }}$ place and higher at the European and World ranking tournaments, and at least in the $7^{\text {th }}$ place and higher at the European, World Championships and the Olympic Games were included into elite group $(n=10)$. Judo athletes who have been successful only on national level competitions have been ranked as non-elite $(n=37)$.

\section{Statistical analyses}

We used basic statistical characteristics for the processing and evaluation of the data obtained. The KruskalWallis one-way analysis of variance was used to compare our three age groups of different sample size. The nonparametric Mann-Whitney $U$-test was used to compare the observed parameters between age groups and the elite and non-elite group. Alpha was set at .05. Effect size was expressed by point biserial correlation $r$, whereby a large effect is .5 , a medium effect is .3 , and a small effect is .1 (Fritz, Morris, \& Richler, 2012). All the statistical analysis was performed using IBM SPSS (Version 20 for Windows; IBM, Armonk, NY, USA).

\section{Results}

Table 1 presents the mean values of judo athletes' body fat, and the circumference of their flexed arm, forearm, wrist, and calf, according to age criterion. Body weight $(U=49.5 ; p=.007 ; r=42)$ statistically differed between cadets and seniors. Arm circumference was statistically different between cadets and juniors $(U=70 ; p=.012$; $r=.43)$, cadets and seniors $(U=21.5 ; p<.001 ; r=.50)$, juniors and seniors $(U=50 ; p=.028 ; r=.41)$, with cadets having the lowest and seniors the highest values. Circumference of forearm differed between cadets and juniors $(U=75.5 ; p=.019 ; r=.40)$, and cadets and seniors $(U=34.5 ; p<.001 ; r=.47)$. Forearm circumferences were the lowest in the cadet category. However, body height, body fat, circumference of wrist, and circumference of calf did not differ among age groups.

Table 2 presents judo athletes' body fat and circumference of flexed arm, forearm, wrist and calf in the elite vs non-elite groups. Elite judo athletes in our research were heavier than non-elite athletes $(U=103.5 ; p=.034$; $r=.48)$ and presented higher forearm circumference $(U=98 ; p=.023 ; r=.33)$ and wrist circumference $(U=82 ; p=.007 ; r=.39)$. Other variables like body height, body fat, flexed arm circumference, and calf circumference were not significant among the groups.

\section{Discussion}

The objective of this study was to characterize and compare some morphological variables of male judo athletes from cadet, junior and senior categories. In our study, cadets presented significantly lower values of arm and forearm circumference compared to juniors and seniors with medium and large effect size. These results are consistent with results of Escobar-Molina et al. (2011) where male cadets also presented the lowest values of flexed arm circumference $(32.0 \pm 0.9 \mathrm{~cm})$ compared to junior and senior Spanish judo athletes. Our seniors presented significantly higher values of arm circumference compared not only to cadets, but to juniors as well. As muscular strength is proportional to muscle size, a bigger arm circumference can be advantageous (McArdle, Katch, \& Katch, 2003). A similar

Table 1

Mean values of age, number of years in judo, body height, body weight, body fat and the circumference of flexed arm, forearm, wrist, and calf in the cadets, juniors and seniors

\begin{tabular}{lccc}
\hline & Cadets $(n=19)$ & Juniors $(n=15)$ & Seniors $(n=13)$ \\
\hline Age & $16.52 \pm 0.77$ & $19.20 \pm 0.77$ & $22.92 \pm 2.25$ \\
No. of years in judo & $10.02 \pm 1.25$ & $11.23 \pm 1.82$ & $13.84 \pm 3.60$ \\
Body height (cm) & $180.21 \pm 5.47$ & $177.00 \pm 6.19$ & $179.23 \pm 7.71$ \\
Body weight (kg) & $72.10 \pm 9.17^{\mathrm{a}}$ & $76.15 \pm 8.43$ & $85.32 \pm 13.13$ \\
Body fat (\%) & $15.75 \pm 2.65$ & $16.28 \pm 2.27$ & $17.53 \pm 2.90$ \\
Circumference (cm) & & & \\
$\quad$ Flexed arm & $30.23 \pm 2.33^{\mathrm{b}}$ & $32.86 \pm 2.61^{\mathrm{c}}$ & $35.46 \pm 2.96$ \\
$\quad$ Forearm & $28.13 \pm 1.70^{\mathrm{d}}$ & $29.70 \pm 1.83$ & $30.80 \pm 1.66$ \\
$\quad$ Wrist & $18.25 \pm 0.70$ & $17.96 \pm 0.58$ & $18.54 \pm 0.63$ \\
Calf & $36.25 \pm 2,02$ & $36.97 \pm 2.11$ & $38.15 \pm 2.72$ \\
\hline
\end{tabular}

Note. $\quad$ acadets significantly different from seniors; ${ }^{\mathrm{b}}$ cadets significantly different from juniors and seniors; ${ }^{\mathrm{c} j u}$ niors significantly different from seniors; ${ }^{\mathrm{d}}$ cadets significantly different from juniors and seniors. 
Table 2

Mean values of age, number of years in judo, body height, body weight, body fat and the circumference of flexed arm, forearm, wrist, and calf in the elite and nonelite groups

\begin{tabular}{lcc}
\hline & Elite group $(n=10)$ & Non-elite group $(n=37)$ \\
\hline Age & $20.80 \pm 2.82$ & $18.70 \pm 2.83$ \\
Number of years in judo & $13.75 \pm 3.19$ & $10.85 \pm 2.27$ \\
Body height $(\mathrm{cm})$ & $181.80 \pm 4.34$ & $178.13 \pm 6.67$ \\
Body weight $(\mathrm{kg})$ & $84.72 \pm 13.99^{\mathrm{a}}$ & $75.05 \pm 9.78$ \\
Body fat $(\%)$ & $16.08 \pm 2.36$ & $16.50 \pm 2.76$ \\
Circumference $(\mathrm{cm})$ & & \\
$\quad$ Flexed arm & $34.20 \pm 3.85$ & $32.06 \pm 3.08$ \\
Forearm & $30.72 \pm 2.27^{\mathrm{b}}$ & $29.01 \pm 1.83$ \\
Wrist & $18.72 \pm 0.44^{\mathrm{c}}$ & $18.11 \pm 0.66$ \\
Calf & $38.14 \pm 2.55$ & $36.70 \pm 2.22$ \\
\hline
\end{tabular}

Note. $\quad{ }^{a}$ body weight in elite group significantly different from non-elite group; ${ }^{\mathrm{b}}$ circumference of forearm in elite group significantly different from non-elite group; ${ }^{c}$ circumference of wrist in elite group significantly different from non-elite group.

correlation was found in the study of Franchini et al. (2007) between the circumferences of an athlete's flexed arm and bench-press one-repetition maximum in the Brazilian national judo team. A bigger arm circumference can be indicative of a higher muscle mass cross-sectional area and consequently of higher power and force output for these segments (Franchini et al., 2007). Strength and conditioning training is a common part of the judo athlete's preparation. Muscular hypertrophy is one of the known adaptive mechanisms on strength training, with a range of intensity between 65-100\% one-repetition maximum, $1-12$ reps, $3-6$ sets (Vanderka, 2016). Multiple-year strength training of experienced senior judo athletes apparently leads to muscle hypertrophy. Muscle hypertrophy and greater body segment circumference are associated with the production of testosterone hormone in particular. The endocrine system releases hormones during exercise. Hormones like epinephrine help the muscles to create the necessary strength. Other hormones like testosterone, growth hormone, and insulin-like growth factor stimulate protein synthesis in the muscles by sending signals to regeneration and growth. Strength training naturally increases the levels of anabolic hormones in the blood around the one-hour mark after exercise, allowing for muscle growth during this time span (National Strength and Conditioning Association, 2008). In the under-18 age category, several factors appear to influence acute serum testosterone concentrations, and may affect whether significant increases occur during or following exercise. Among these factors is the onset of puberty. Since testosterone production in prepubescent boys is very low, prepubescent male athletes lack sufficient quantities of the hormone to induce noteworthy hypertrophy. Independently or in various combinations, exercise variables can increase serum testosterone concentrations in boys and younger men. The most common hormonal response is to the use of high exercise volume, heavy weight, short pauses, and the use of exercises that focus on large muscles (Kraemer, Vingren, \& Spiering, 2008). This type of strength training is used in senior judo categories.

Circumferences of wrist and calf, and surprisingly, body fat, did not differ between age groups. The calf circumferences of our seniors are identical to those of Escobar-Molina et al. (2011) $(38.0 \pm 1.5 \mathrm{~cm})$, however, the values of their cadets $(39.1 \pm 1.0 \mathrm{~cm})$ and juniors $(38.4 \pm 1.1 \mathrm{~cm})$ are higher. These authors also did not confirm significant differences between age groups in this parameter.

The wrist circumferences of our cadets, juniors and seniors are identical to the measured values of the Brazilian A-team and elite judokas (Franchini et al., 2007, 2005).

Body fat in all three age groups was higher than most authors have reported (Clarys, Geelen, Aerenhouts, Deriemaeker, \& Zinzen, 2011; Escobar-Molina et al., 2011; Štefanovský, 2015). Escobar-Molina et al. (2011) also did not confirm the significant differences in body fat between age groups. Based on the findings, we can conclude that body fat of judo athletes in our study is not an appropriate discriminative factor among the age categories.

When the performance criterion was taken into consideration, elite judo athletes in our study had significantly higher values of forearm and wrist circumference 
compared to the non-elite group with medium effect size. According to Dias, Wentz, Külkamp, Mattos, and Goethel (2011), judo athletes spend a considerable amount of time grasping the judo-gi (the jacket) of the adversary (using the kumikata). The kumikata is the first contact between two athletes in the fight and provides the basic support for the execution of different kind of techniques. Attacking on the same side of the kumikata increase the chance of scoring and winning the combat, independently of sex and weight category. Performing same-side attacks by kenka-yotsu (right versus left) is the most effective, especially for lightest weight judo fighters. Perform same-side attacks by ai-yotsu (both fighters using right or left grip at the same time) and only the athlete attacking performing the grip increased the likelihood of winning the combat (Courel, Franchini, Femia, Stankovic, \& Escobar-Molina, 2014). Therefore, the ability of maintaining the grip force for long periods might be an important aspect in judo competition. Opponents are continuously utilising their grip, actively trying to pull or push their opponent off balance (Krstulovic et al., 2005). The power and strength of the forearm, as well as the wrist strength, are likely limiting factors of sports performance in judo. As mentioned above, a higher circumference of these body segments (forearm and wrist) can be indicative of a higher muscle mass cross-sectional area, and consequently of higher power and force output. This is the impact of long-term judo training as well as the specific strength training, which elite judokas undergo throughout the whole season. One study confirmed significant differences in the circumference of forearm and wrist among the elite and non-elite judo athletes (Franchini et al., 2005). Two studies (Franchini et al., 2007; Krstulović et al., 2005) did not confirm any significant differences in circumference of any of these body segments. Therefore, further research is needed in this field.

Our results did not confirm the assumption that elite judo athletes consistently have a very small percentage of body fat compared to their non-elite counterparts. These findings are in accordance with study of Dird et al. (2015). It is necessary to state that our athletes in both groups (elite and non-elite) had much higher body fat values than reported in other studies (Farmosi, 1980; Franchini et al., 2011; Koury, Oliveira, Portella, Junior-Oliveira, \& Donangelo, 2005; Sertic, Segedi, \& Molanovic, 2006; Sterkowicz, Zuchowicz, \& Kubica, 1999). The modal body fat value for top-level male judo athletes is approximately $10 \%$. However, according to our findings, body fat does not necessarily predict performance in judo, where technique, tactics, and mental aspects are essential factors for success. A judo athlete who does not match the optimal anthropometrical profile can still succeed through improved or superior techniques and tactics (Franchini et al., 2007). However, the findings of our study must be interpreted with caution, due to the fact, that we did not divide the judo athletes according to their weight categories, which may be the subject of research in a further study. Next study can also verify the relation between the wrist, arm and forearm circumferences and production of absolute and relative maximal muscle strength. Finally, ultrasound technology is still rarely used in judo practice to measure skinfold thickness and total body fat. Further studies are needed to test its reliability compared to other methods.

\section{Conclusion}

Forearm and wrist circumference is a reliable discriminative factor and should be taken into consideration, especially when selecting judo athletes into elite teams. However, we did not confirm that subcutaneous fat is a parameter able to distinguish between judo athletes with different performance status across various age categories.

\section{Acknowledgments}

The authors would like to thank to the coaches who kindly agreed with participation of their athletes in this study during the training camp "V4" which took place in Bratislava, Slovak Republic in 2015.

\section{Conflict of interest}

There were no conflicts of interest.

\section{References}

Bushberg, T. J., Seibert, A. J., Leidholdt, M. E., \& Boone, M. J. (2002). The essential physics of medical imaging (2nd ed.). Philadelphia, PA: Williams \& Wilkins.

Callister, R., Staron, R. S., Fleck, J. S., Tesch, P., \& Dudley, A. G. (1991). Physiological characteristics of elite judo athletes. International Journal of Sports Medicine, 12, 196-203.

Castarlenas, J. L., \& Planas, A. (1997). Estudio de la estructura temporal del combate de judo [Study of the time structure of judo fight]. Apunts Educación Física y Deportes, 47, 32-39.

Clarys, P., Geelen, B., Aerenhouts, D., Deriemaeker, P., \& Zinzen, E. (2011). Estimation of body composition in adolescent judo athletes. Journal of Combat Sports and Martial Arts, 2, 73-77. 
Classens, A., Beunen, G., Wellens, R., \& Geldof, G. (1987). Somatotype and body structure of world top judoists. Journal of Sports Medicine and Physical Fitness, 27, 105-113.

Courel, J., Franchini, E., Femia, P., Stankovic, N., \& EscobarMolina, R. (2014). Effects of kumi-kata grip laterality and throwing side on attack effectiveness and combat result in elite judo athletes. International Journal of Performance Analysis in Sport, 14, 138-147.

Dias, A. J., Wentz, M., Külkamp, W., Mattos, D., \& Goethel, M. (2011). Is the handgrip strength performance better in judokas than in non-judokas? Science and Sport, 27, 9-14.

Drid, P., Casals, C., Mekic, A., Radjo, I., Stojanovic, M., \& Ostojic, M. S. (2015). Fitness and anthropometric profiles of international vs. national judo medalists in halfheavyweight category. Journal of Strength \& Conditioning Research, 29, 2115-2121.

Escobar-Molina, R., Franchini, E., Huertas, J. R., Sterkowicz, S., Carratalá, V., \& Gutiérrez-García, C. (2011). Anthropometrical profile of elite Spanish Judoka: Comparative analysis among ages. Archives of Budo, 7, 239-245.

Farmosi, I. (1980). Body-composition, somatotype and some motor performance of judoists. Journal of Sports Medicine, 20, 431-434.

Franchini, E., Artioli, G. G., \& Brito, J. (2013). Judo combat: Time-motion analysis and physiology. International Journal of Performance Analysis in Sport, 13, 624-641.

Franchini, E., Del Vecchio, F. B., Matsushigue, K. A., \& Artioli, G. G. (2011). Physiological profiles of elite judo athletes. Sports Medicine, 41, 147-166.

Franchini, E., Nunes, V. A., Moraes, M. J., \& Del Vecchio, B. F. (2007). Physical fitness and anthropometrical profile of the Brazilian male judo team. Journal of Physiological Anthropology, 26, 59-67.

Franchini, E., Takito, M., Kiss, M., \& Sterkowicz, S. (2005). Physical fitness and anthropometrical differences between elite and non-elite judo players. Biology of Sport, 22, 315-328.

Fritz, O. C., Morris, E. P., \& Richler, J. J. (2012). Effect size estimates: Current use, calculations, and interpretation. Journal of Experimental Psychology, 141, 2-18.

Koury, J. C., Oliveira, C. F., Portella, E. S., Junior-Oliveira, V. A., \& Donangelo, M. C. (2005). Effect of the period of resting in elite judo athletes. Biological Trace Element Research, 107, 201-211.

National Strength and Conditioning Association. (2008). Posilovani od A do Z [Strength training from A to Z]. Brno, Czech Republic: Computer Press.
Kraemer, W. J., Vingren, J. L., \& Spiering, B. A. (2008). Endocrine response to resistance exercise. In T. R. Baechle \& R. W. Earle (Eds.), Essentials of strength training and conditioning (3rd ed., pp. 53-54). Champaign, IL: Human Kinetics.

Krstulović, S., Sekulić, D., \& Sertić, H. (2005). Anthropometrical determinants of success in young judoists. Collegium anthropologicum, 29, 697-703.

Kubo, J., Chishaki, T., Nakamura, N., Muramatsu, M., Yamamoto, Y., Ito, M., ... Kukidome, T. (2006). Differences in fat-free mas and muscle thicknesses at various sites according to performance level among judo athletes. Journal of Strength and Conditioning Research, 20, 645-657.

Little, N. G. (1991). Physical performance attributes of junior and senior women, juvenile, junior and senior man judokas. Journal of Sports Medicine and Physical Fitness, 4, 510-520.

Marcon, G., Franchini, E., Jardim, J. R., \& Neto, B. L. T. (2010). Structural analysis of action and time in sports: Judo. Journal of Quantitative Analysis in Sports, 6(4), 1-13.

McArdle, W. D., Katch, F. I., \& Katch, V. L. (2003). Exercise physiology: Energy, nutrition and human performance (5th ed.). Philadelphia, PA: Lippincott, Williams \& Wilkins.

Parrillo, J., \& Greenwood-Robinson, M. (1993). High-performance bodybuilding. New York, NY: Perigee Books.

Sertic, H., Segedi, I., \& Molanovic, D. (2006). Anthropological and fitness status of Croatian judoists. Archives of Budo, 2, 24-27.

Štefanovský, M. (2009). Džudo 1 - teória a didaktika [Judo 1 - theory and didactics]. Bratislava, Slovakia: Comenius University in Bratislava.

Štefanovský, M. (2015). Fyziologické, motorické a somatické charakteristiky džudistov z hladiska veku a úrovne trénovanosti [Physiological, motor and somatic characteristics of judokas according to age and training status]. Bratislava, Slovakia: Slovak Scientific Society for Physical Education and Sport.

Sterkowicz, S., Zuchowicz, A., \& Kubica, R. (1999). Levels of anaerobic and aerobic capacity indices and results for the special judo fitness test in judo competitors. Journal of Human Kinetics, 21, 115-135.

Vanderka, M. (2016). Silový tréning pre výkon: vedecká monografia [Strength training for performance: Research monograph]. Bratislava, Slovakia: Slovak Scientific Society for Physical Education and Sport.

Wagner, R. D. (2013). Ultrasound as a tool to assess body fat: Review article. Journal of Obesity, 2013, 280713. 